\title{
Retraction Note: Development and application of copper-nickel zirconium diboride as EDM electrodes manufactured by selective laser sintering
}

\author{
Tiago Czelusniak ${ }^{1} \cdot$ Fred L. Amorim ${ }^{1} \cdot$ Armin Lohrengel $^{2} \cdot$ Camila F. Higa $^{1}$ \\ Published online: 17 January 2021 \\ (C) Springer-Verlag London Ltd., part of Springer Nature 2021
}

\section{Retraction Note: The International Journal of Advanced Manufacturing Technology (2014) 72:905-917 https://doi.org/10.1007/s00170-014-5728-4}

The Editor-in-Chief has retracted this article [1] because it contains material that significantly overlaps with other published articles [2, 3]. F.L. Amorim, T. Czelusniak, and C. Higa do not agree to this retraction/ A. Lohrengel has not responded to any correspondence from the editor/publisher about this retraction.

\section{References}

1. Czelusniak T, Amorim FL, Lohrengel A et al (2014) Development and application of copper-nickel zirconium diboride as EDM electrodes manufactured by selective laser sintering. Int J Adv Manuf Technol 72:905-917. https://doi.org/10.1007/s00170-014$5728-4$

2. Amorim FL, Lohrengel A, Neubert V, Higa CF, Czelusniak T (2014) Selective laser sintering of Mo-CuNi composite to be used as EDM electrode. Rapid Prototyping J. https://doi.org/10.1108/RPJ-042012-0035

3. Amorim FL, Lohrengel A, Schaefer G, Czelusniak T (2013) A study on the SLS manufacturing and experimenting of TiB2-CuNi EDM electrodes. Rapid Prototyping J 19:418-429. https://doi.org/10.1108/ RPJ-03-2012-0019

Publisher's note Springer Nature remains neutral with regard to jurisdictional claims in published maps and institutional affiliations.

The online version of the original article can be found at https://doi.org/ 10.1007/s00170-014-5728-4

Fred L. Amorim

fred.amorim@pucpr.br

1 Mechanical Engineering Graduate Program, Pontifical Catholic, University of Parana - PUCPR, Av. Imaculada Conceição, 1155-Prado Velho, 80, Curitiba 215 901, Brazil

2 IMW-Fritz-Süchting-Institut für Maschinenwesen, Technische, Universität Clausthal-TUClausthal, Robert Koch Strasse, 32, 38678 Clausthal-Zellerfeld, Germany 